平成 3 年度日本産業動物獣医学会 講演要旨一東 北

期

日: 平成 3 年 9 月 27 日

会

場：秋田市・秋田ビューホテル

地区学会長：村上大蔵（岩手大学農学部）

地区学会担当地方会：秋田県獣医師会

発表演題数 : 24 題

地区学会長賞受賞演題 : 演題番号 5

〔演 題 名]泌乳初期と最盛期の乳牛における血液 成分, とくに血糖値とルーメン液揮発 性低級脂肪酸 (VFA) および乳成分の関 係

〔発 表 者〕谷津 實 佐藤 繁 吉目木勝策 木村喜正 今野清勝 高橋孝幸 （宮城県農共連白石家畜診療所）

1. 放牧牛で観察されたタイレリア寄生赤血球ゴースト 亡赤外原虫

小堤知行

（宮城県石巻家畜保健衛生所）

1. はじめに

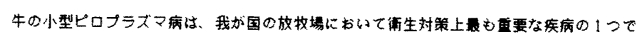

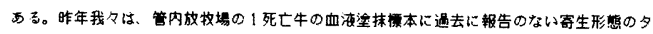

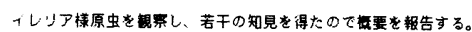

2. 材料よよび方法

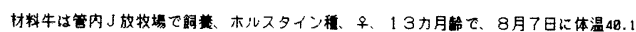

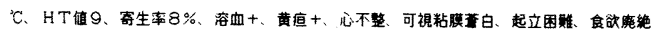

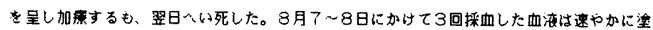

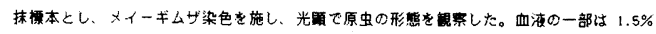

Paraformaldehyde+ $0.5 \%$ Glutalaldehydeと $1 \% 0$ smium $て 二$ 重固定後、常法认従って处理し

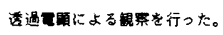

3. 成就

光顆的には、全ての栖本でィーギムザ染色により低染色性を示す原虫奇生赤血球及び赤

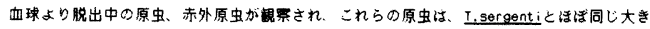

き、同し染色性て、主に卯円形加的形を呈していた。

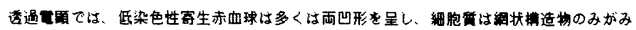

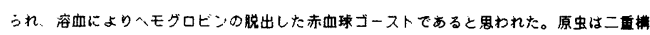

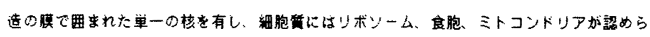

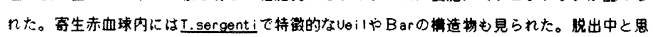

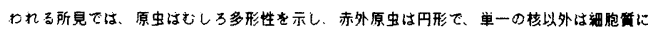

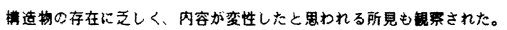

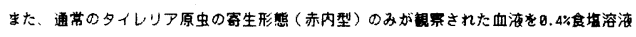

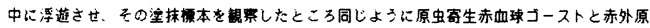

虫が見られた。

4. 考察

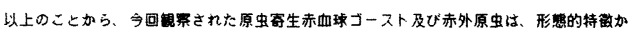

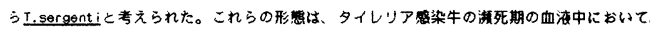

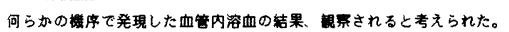

2. 悪性カタル熱の発生例

小沼成尚* 伊藤 隆 田中 篤 高橋幸男 木村 衆 渡部 満 志村 統

（* 秋田県北部家畜保健衛生所）

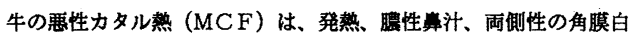
濁、リンパ節の腫大を主改とする急性、致死性の疾病であり、我が国 では1954年に初めて報告されて以来散発的な発生を見ている。

今回、当所管内の肉用牛一贯経営農家 (繁殖10頍、肥育16頭、子牛 6頭、計32頭) において、慗殖および肥育牛 2 頭に悪性力タル熱の発 生があつた。

1990 年 5 月23日に、畜含内の肥育牛 1 頭が発熱、元気消失、食欲不 尉、両僛性角膜白濁、流涙、流涎を呈し、㽬医師が治療を行つたが、 削謏が著しくなり定状が回復しないため鑑定殺を実施した。

病理組織所見で、全身性の血管炎、リンパ球様細胞の浸潤を特徵と する血管周囲炎及び非化腰性脳炎などがみられたことから、本症を $\mathrm{M}$ CFと埥断した。

さらに、同年 7 月26日に放牧衛生検査の際、同様な症状を呈してい た繁殖牛 1 䫓を発見した。鑑定殺の結果、病理組織所見で同一所見が 得られたことから本定と診断した。

発生農家では、1986年からめん羊 4 暊を牛合内で飼育しており、ま た1990年の 2 月上旬にめん羊の 1 頭が分婏していることから、めん羊 と牛との疫学的関連を知る目的で、ウシカモシカヘルペスウイルス 1 型を用いた間接営光抗体法を実施した。検査は発定牛 2 頭および同居 牛20頭、放牧牛16頭、めん羊32頭について行い、発定牛 2 頭は $\times 128$ 、 X64と高い抗体価を示し、当該農家のものを含むめん羊 12 頍に有意な 抗体 $(\times 8 \leqq)$ が認められた。以上のことから、本症例はめん羊由来 のMCFと考えられた。

また、病変部および血管周囲に浸潤した緗胞は、家畜衛生試験堨で 実施した牛リンパ球に対するモノクローナル抗体を 1 次血清としたA BC染色により、キラーまたはサプレッサーTリンパ球であることが 示された。

\section{3. 子豚大腸菌性下痢症の治療並びに予防試験}

鎌田久祥* 佐藤林治 小西潤一 熊谷清孝 佐々木専悦 （）秋田県南部家畜保健衛生所）

\footnotetext{
哺乳豚の下湤は、㕕成上大きな経济的损失を与える重要な疾病であり、 その対策として、日常の飼美境境改善を重点的に指䓕しているが、比僌的 棵境の良好な義豚埸においても発生が認められる。分離株の多くが種々萩 剖に対し感受性を示さず苦虑している。したがつて化学燎法による対策も

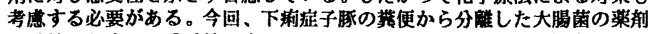
感受性を調查し、感受性の高かったオキソリン酸（以下、OA）の製削を

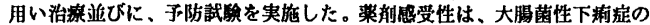
発生がみられた44顋から分婏された51株について、OAが最も高くその最 小発育阻止摆度 (M I C) は. $0.2 \sim 1.56 \mu \mathrm{g} / \mathrm{ml}$ 簀囲であつた。 1989年11月〜12月にかけ、下潎の発生が㑇められた 3 農場の8〜19日龁の

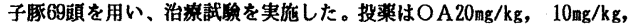

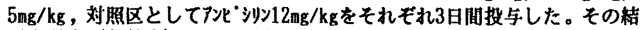

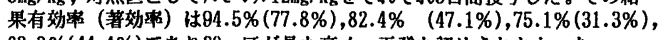
83.3\%(44.4\%) であり20mg区が最も高く、再発も眼められなかつた。

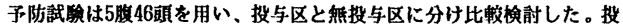

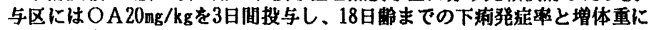
ついて調查した。

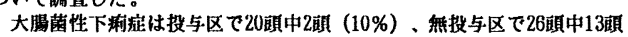
(50\%) に、発生が綛められ、両区において、危俛帤 $5 \%$ で有意差が瑟め られた。又、体重の推移でみると投与区の正常䀠では $5.41 \pm 0.90 \mathrm{~kg}$ 、無投

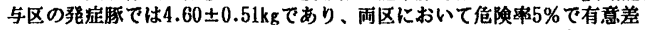
が㒛められた。以上のことから、OA投与は治潦效果のみならず子防対策 の一方法としても有奻であることが示唆された。

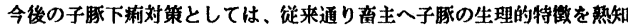

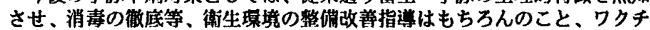

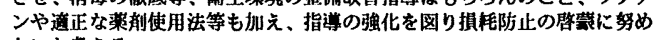
たいと考える。
} 


\section{4.一孵化場に発生した鶏脳脊髄炎の発生例} 柿野 淳* 志村 統 （）秋田県中央家畜保健衛生所）

1.はじめに

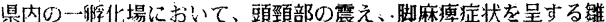
が多発している旨連絡があり、検査を実施した結果、典型的な鵎脳 会能炎と診断されたのでその概要を報告する。

2 . 診 断

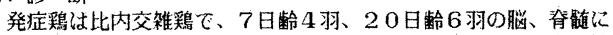
病理組織学的所見で高度な囲管性細胞浸潤と大型神経細胞の中心性 虎斑融解像が認められて。

3. 発生状況

1) 種䳕 (1012羽)

産卵率：65〜80\%から37〜38\%まで低下し、典型的なV字形を 示した。また回復まで15日を要した。無精卵率：10〜12\%から $23 \%$ まて昇し、回復まで30日を要した。卯化率：70〜80等か ら60〜61\%まで低下し、回復まて21日を要した。卯重：63.5\% から62.5gに低下した。また回復後は64.5gまで上昇した。低下 期間は14日であった。

2) 雛 (3220羽)

感染前期に産卵され孵化した雊は、8日まで死亡鶏があり、60 日まではほとんど淘汰哭鳥で出荷率は95\%から40\%に低下した。後 期の出荷率は78\%であった。また開放舎の死亡淘汰状況はそのビ ークがはっきりと出ていないが、ウイン゙レス舎では6日に死し 鷄、26日に湟汰鵎の大きなピークが認められた。

4. 考察

最近、高級鶏肉を地方の特産品として生産する動きが活発になっ ているが、閉鎖的な環境にあるものが多く今後も散発的に発生する 可能性があると思われる。このような事例を踏まえ、卿化場におい ては産卯期前に必ずワクチン接種をすることが重要と思われた。ま たウイドレス舎は開放舎に比べ病原体が一度舎内に侵入した場合、感 染は早くその被害は大きくなることが同えた。

5. 泌乳初期と最盛期の乳牛における血液成分, とくに 血糖值とルーメン液 VFA および乳成分の関係 谷津 實 佐藤 繁 吉目木勝策 木村喜正 今野清勝 高橋孝幸 （* 宮城県農共連白石家畜診療所）

1.はじめに

代謝プロファイルテストを利用して農家の咱䓪管理指道を行なうための基脴 的資料を得る目的で，泌乳初期と最盛期の乳牛における血液成分，とくに血桾 值とルーメン液揮発性低級脂肪酸(VFA) およひ乳成分の関係を検討した。 2. 材料および方法

供試牛は泌初袺あるいは最盛期に区分される乳牛で，血糖値が高値を示す 牛と低值を示す牛を選び, 11戸の農家功 3頭ないし6頭ずつ, 計49頙を用い た。血液成分は，エネルギー代謝検查として血糖、遊離脂肪酸、コレステロー ル(Chol)，タンパク代謝輠査として尿素絰素(BUN)，総タンパク，アルブミン (Alb) の各項目を用い，経口的に採取したルーメン液は，ガスクロマトグラフ 法によりVFA濃度を、また, 検診当日の夕方と翌朝に採取した牛乳は，公定法 により乳脂肪，乳タンパク，乳糖および無脂固形を測定した。

3. 成 績

血糖值および総 VFA濃度の平均值は61 mg/dlおよひ $5.26 \mathrm{mM} / \mathrm{dl}$ と低値を示し，

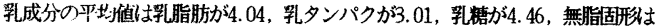
8.48であった。血液成分と乳成分との間では，血桾値と乳タンパクおよび無脂

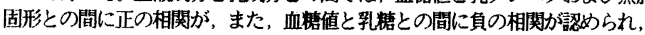
その他，Chol，BUN および Albと乳量との間にも正の相関か認められた。

一方, 血糖値力 $60 \mathrm{mg} / \mathrm{dl}$ 以上の正常血糖牛 $(\mathrm{n}=25)$ と60 mg/dl以下の低血榶牛 $(\mathrm{n}=24)$ に分類し，各群ごとに血桾値と乳成分および VFA濃度との間の関係を㭘 討した結果，正常血糖牛では乳脂肪，叱タンパクおよび無脂固形との間に正の 相関が，また，乳榶との間に負の相関か認められた。低血糖牛では乳タンパク， 酶酸抽よ゙プロピオン酸濃度との間に負の相関か諰められた。

4. 考 察

以上のことから，泌乳初期と最盛期の乳牛では，血桔值とルーメン液VFA濃 度が乳成分に影響すること，また，血糖值が低値を示す牛では，これらの関係 が不安定になることが明らかにされた。このことから，代謝プロファイルテス 卜を利用して飼養管理指導を行なう場合，とくに分娭後の工ネルギー給与に注 意することが重要であると考えられた。
6. 乳中体細胞数測定の実態

藤井英直

（福島県酪連生乳検査所）

年々高度化していく消费者ニースに応える高品質牛乳を供給するため。 県酪連は体細胞数を迅速に测定する営光光学式体細胞数測定機（フォス マチック 360 ) を学入し 1 年半を経過した。

当検査所では、生乳を分析した「牛乳の分析結果」表を生産者個々に 配布し生産者の乳質改善への钼心を促している。乳成分が基準以下の場 合には飼料計算を促したり、衛生的な販質では体細胞数による損失乳量 や損失乳代を知らせ、乳質の総合評価も行つている。また、個人乳量 の前年比や計画比も毎月情報として提供している。今回、体細胞数测定 機による娜定值と従来のブリード值とを比較し機器测定値の信頼性を確 認すると共に、県酪連管轄下にある酪農家のバルク乳及び固体乳の体細 胞数の実態について調查し、下衭の結果を得た。

\section{方法}

生産農家数- - 1, 016 戸

検查検体数ーーバルク笔 48,769例、個体乳 227 例

実施期間- - 平成 2 年 4 月 平成 3 年 3 月

公定法の標準值 (ブリード値) とフォソマチック 360 の比較

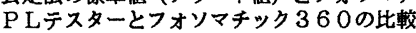

体細胞数と一日乳量及ひ推定損失乳量の推移

結果早㯕琴

1、公定法の漂準值とフォソマチック 360 の体細胞数澌定值の比較 両者間の差の平均值は $2.2 \%$ 、変動係数の平均值は $3.9 \%$ であ

りフォソマチック 360 による体細胞数測定値の信頼性は高かつた。

2、体細胞数の分布

227 例の调体礼および約 4 万8千例のバルク乳について調べた体細 胞数は 2 峰性に分布し、個体乳の第一峰では 10 万未渾、第 2 峰では

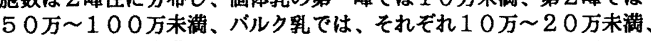
30万〜 50 万末澏にあった。

3、PLテスターとフォソマチック 360 の比較

体細胞数と P Lテストの関你を検討した結果は、PLテスト(一)群で は $77 \%$ は 20 万末满であつたが、(十ー)群およひ $(1+)$ 群では約半

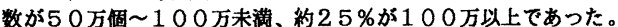

4、体細胞数と一日乳量及び推定損失礼量の月别推移

体細胞数の增加と推定損失乳量は同じような傾向にあり、体細胞数と 一日乳量の推移は反比例していた。

7. 乳房炎発生の易患性体質に関する調査研究 佐藤 彪* 佐藤修一 中野和光 五十嵐哲雄 清野哲夫 $(*$ 村山共同家畜診療所 山形県 $)$

1.はじめに

乳房炎多発の要因に遗伝性体晢が背景にあると考えられている。Hamor は易患性体質が疾病の多発や難治性と関連しているととを指摘し、佐々木 と清水らも抵抗力の個体差を体質であると示唆しているか、今だに同定さ れていない。我々も乳房炎の発生は、体質との関わりが極めて深いと考え 血統調査を試みた。その結果、易患性の体質を同定するととができた。 2. 供試牛と方法

( 1) 1988 1990年における㵠乳牛441 頭と乳房炎201 頭について、年令 別に比較調査した。（2）1990年における分婏牛349 頭の乳房炎205 頭に つて、月別分婏と発生, 泌乳期別発生と再発について調查した。(3) 血統の明らかな推乳牛374 頭の乳房炎119 頭について、種雄牛別発生と再 発、さらに父と祖父との組み合わせによる発生、ならびに家系を $3 \sim 5$ 代 前に逆上り、発生と血緑関係を調査し、集団遺伝学的解析を試みた。

3. 成 績

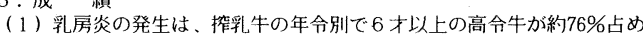
分婏牛の58\%に発生し、夏期に多発し月別では5-9月の多発が $1-8$ 月の分婏牛で、分娩時の発生は約 $25 \%$ 占め、泌乳期別発生では周産期の発 生が著しく高かった。また再発牛は発生牛の約 $42 \%$ 占めていた。

(2) 種雄牛別発生では、非羅患種雄牛 12 頭, 100 \%䍜患種雄牛 4 頭とそ の間の $50 \%$ 以上䍜患種雄牛 10 頍、50\%以下䍜患種雄牛 26 頭であった。さら に発症35頭の父と祖父との組み合せの発生数別で、A B C D 区に分けると A区が約43\%を占め、4区に明らかな差が認められた。

(3) 発生牛119 頭の血縁発生34組は、10Typek分類され83頭の発生が観 察された。そのうち親子関係が最も多く、次いで姉妹. 親子姉妹の発生が 多く、混合型の一家系に 7 頭の発生を唡出し、遗伝性が解明された。

4. 考 察

今回の調査により、乳房炎は、月別，年齢別、泌乳期別の発生が抵抗力 の低下と、さらに再発を重ね、また、乳房炎多発の背景に、㮔雄牛によっ ては、䍜患し易い形質が世代に拡散され、同一家系内に多発しており、乳 房炎に関与している遺伝子の数は、種雄牛に少性ホモ牛が含まれていると 仮定した場合、因子が1つであるとしても発生率との間に矛盾はなく、易 患性体質の乳房炎は、常染色体性単一劣性遗伝様式によって発生するてと が同定された。従って、乳房炎の発生防止は、今後、発生の背景にある保 因種雄牛の遺伝子検定の重要性を示唆したものである。 
8. 牛に対する硬化包帯の圧縮荷重試験について 原 茂雄* 冨澤伸行 加崎弘康 菅野 弘

(* 岩手大学農学部)

1.はじめに

牛の運動器病、ことに骨折は年々增加の傾向にある. 骨折治療 の基本は保存療法にあるという理論からすると、固定包帯の使用 頻度む多く、その強度と安全性はことに重要である. 最近、軽量 て晒れた硬化包帯が開発されているがそれらのむつ特性について 不明な点むある. 今回、安全で経济的な硬化包帯の装着のために、 その力学的強度について基礶的検即を行ったところ有益な成績が 得られたので報告する。

2. 材料と方法

硬化包帯としてプラスチック包帯 (Vetcast Plus、スリーエム 薬品製)および石衰ギプス包带 (Plasrun-Gypus、東京衛材研製) を用いた. Vetcast Plusでは2〜7層巻、石言ギフスス包帯では5 〜13層巻の各々について円筒状のギブスのモデル（高さ100mm 直径67mm) を作製し、7日後にTensilon万能試駼器 (UTM-III-500、 Toyo Baldwin 製) で500kgまでの圧縮荷重試駼を行った。そこで ほほ500kgに耐える巻数が把握できたので、Vetcast Plusでは 6 層巻について作製後5 120分、石素ギブス包帯では13層巻につい て作製後10〜120分での圧縮荷重試驗を行った。

3 . 結果

Vetcast, Plusでは 6あるいは7 層巻で500kg以上の圧縮荷重に耐 えることが認められた。 5 首巻で $482 \mathrm{~kg} 、 4$ 層巻て $352 \mathrm{~kg} 、 3$ 首巻 $220 \mathrm{~kg} 、 2$ 屏巻で84kgに耐えられた。 さらに、この6届巻は作製後 5 分では87kg、10分では $242 \mathrm{~kg} 、 20$ 分では $340 \mathrm{~kg} 、 30$ 分では $435 \mathrm{~kg}$ 、 60分では487kgに耐えられ、120分では500kg以上の圧縮荷重に耐え

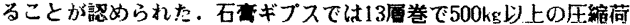
重に耐えることが羿められたが、作製後60分では辛うじて $282 \mathrm{~kg} に$ 耐えた。

4. 考察

以上のことから硬化包带は巻数に态じ、さらに装着してからの経 過時間に上り強度に差が認められた. 硬化包带の装着に当たっては その性筫、患肢の負重や骨折の状況を十分に考虑して使用すること が重要でることが示唆された。

9. 競走馬の滕蓋骨脱臼における内唄滕蓋靱帯切断の応 用について

山口俊男* 勝見 晟 （* 山形県くみあい畜産研修センター）

1.はじめに

重度な本疾病の多くは整復困费であり、徉来予後不良とされてきた。外科的療法 で、内則滕益䩗带切断術が知られているが我が国での報告はなく競走馬での予後 が不明であったため容易に実胍することがてきなかった。今回、整復しても起立時

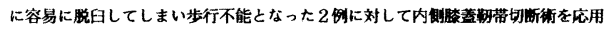
し良好な粘果を得たのて報告する。

2. 材料及ひ方法

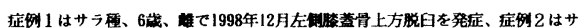

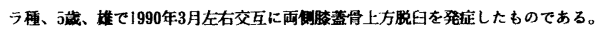

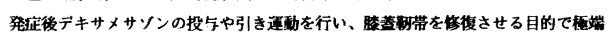

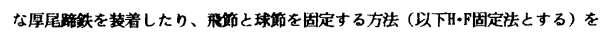

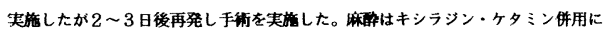

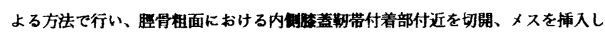

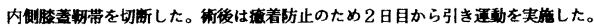

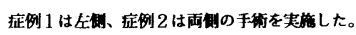

3. 成 績

術後 7 日目まで支披を呈したがその後徐々に回復し、症例1では 36 日目に症例 2 では 40 日目に馬場ての謝教を開始した。レース出走は症例 1 ではイカ月䥻て 1 4 戦 1 着 3 回 2 着 4 回 3 着 2 回、症例 2 では 3 力月後で 12 戦 1 着 3 回 2 着 2 回 3 着 1 回の好成猎でおった。

4. 考察

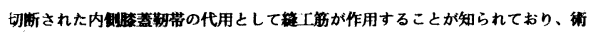

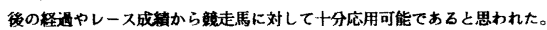

10. 豚の市販鉄含有飼料給与による骨異常の発生

\section{安部啓一 種市 淳* \\ (* 山形県置賜家畜保健衛生所)}

（はじめに）100日齢の豚16頭が、発育不良、起立不能を示し、鉄過剩投与に 上る冎疎筀症と診断。（材料と方法）発症子豚16頭中の3頭を病理検査に供し、 同居豚5頭は10日間隔で採血し生化学的検查を実施。（再現試験） $3 \%$ 添加区 に2頭、0.2\%区および無添加区は各 1 頭づつ試験に供し、市販創料に消县用 鉄剂を上記量各々添加し49日柃から120日齢まで不断給䬧、経過血漿の生化学 検查を実施、121日齢で病理解剖。投与飼料並びに試験豚の臟器中鉄の定量分

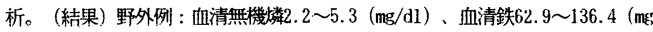

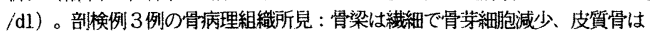
ハバース管の著明な拡張。その他の組織所見 : 所臟器にへモジデリ沈着。疫学調 查 : 鉄を約 $22 \%$ 含む消臭用鉄剂を 40 日齢加 52 2 3\%持続的に添加。投与中止後 10日目の血清生化学検榃血清無機燐上昇、鉄濃度の低下。

再現試験 : $3 \%$ 添加区の飼料掑取量的 $30 \%$ 減少、剖検時体重他他の 2 区平均 $60 \mathrm{k}$ gに対し 33kg。血棩中C A 燐比は 3\%添加 2 週目に4.0〜5.0。大腿骨中のC A と無機燐の定量分析 : 3\%添加区67 79 (mg/g DM) 28〜33( $\mathrm{mg} / \mathrm{g} \mathrm{DM})$ 。臟器 中鉄含量 : $3 \%$ 区肝78～83 (mg/100g DM) 脾80 91 (mg/100g DM)。下腿骨の) 軟X線写真所見：3\%区、骨端線～骨幹部陰影濃度隇少。組織所見：3\%区㺟 骨近位端、綝細な骨梁、骨端軟骨層の厚み変化せず。脛骨近位端の軟骨内骨化 像、肥大軟骨䋥胞の軽度の配列不整と極めて幅の狭い一次海綿骨形成。 骨量定量 : 軟X線像をもとにデジ多仿 入力の画像解析、8.6mm平方 $\times 3$ 視野当り 骨梁数、3\%区107、対照区67、骨梁面積、3\%区3.5 mm平方、対照区9.3m平方 (考察) 消莫を目的と鉄剤の過剩投与により発育期の子豚の長骨に骨疎鬆症を 観察した。Vernejoulらは鉄の非経口的過㮃投与試験により、上皮小体機能、 類骨の石灰化および破骨細胞による骨吸収能に变化なく、定量的形態測定結果 から鉄の沈着を伴った骨芽紐胞機能の低下を示唆している。経口的鉄過剩投与

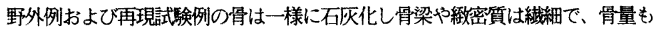
少なく骨形成能の低下がうかがわれた。以上から持続的な鉄剂の過乘経口投上 によって発育期の豚の長骨に骨疎踑症が引き起こされ得るものと考察した。

\section{1. 乳牛における塩酸キシラジン尾椎硬膜外注射の臨床} 応用

\section{橋本良也* 安田賢蔵 高瀬勝晤 日笠喜朗 小笠原成郎}

（）安田畜研 青森県）

I . はじめに

牛における尾推硬膜外麻酔は処置、手術において侵れた麻醉法であり汎用されている。 しかしながら腰瘘症状あるいは騒嗳を呈し場合によっては起立不能に陷る症例も散見され る。 $\alpha_{2}$ 受容体作動薬である塭酸キシラジン (以下 X y) を硬膜外に投与すると鎮痛効果 が得られることが報告されるようになり今回 $\mathrm{X} y$ 尾推硬膜外注射をホルスタイン種成牛で

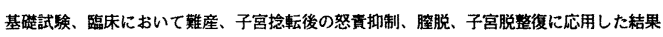
、安全性および有用性において良好な結果を得たのでその概要を報告する。

II. 材料および方法

基礎試駼には健康なホルスタイン種成牛 4 䫒を用い、臨床応用には平成 2 年 7 月から平 成 3 年 9 月までに発生した子宮脱 10 例、朣脱 1 例、難産子宮捻転等の後怒責の著しく強 いもの 4 例の計 15 例を用いた。

方法（1）基碳試蜍では X y $0.01 、 0.03 、 0.05 、 0.10 \mathrm{mg} / \mathrm{kg}$ をそ れぞれ生理食塩水 $15 \mathrm{~m} 1$ で希积し尾推硬膜外麻酔法の術式に従い第 1 第 2尾推間に注射 した。（2）臨床応用では基懒試稌結果よりX y $0.05 \mathrm{mg} / \mathrm{kg}$ を標準量とし（1） の方法で注射した。

III. 成結

基䃈試験より尾部、会陰部の痛賞反応の消失および安全性は X y $0.05 \mathrm{mg} / \mathrm{kg}$ おいて最も良好であった。臨床例にX y 0.0 $043 \mathrm{mg} / \mathrm{kg} \sim 0.056 \mathrm{mg} / \mathrm{kg}$ を 投与した結果、無痛覚発現までの時間は平均 12.1 分士1.5 (S D) 、効果持絸時間 では229.3分士41.9（S D)、䅅徽な鎮静が見られ騒嗳および後肢運動失調は見 られなかった。 IV. 考察

$\mathrm{X}$ y $0.043 \mathrm{~m} \mathrm{~g} / \mathrm{kg} \sim 0.056 \mathrm{mg} / \mathrm{kg}$ の尾椎硬膜外注射は子宮脱整復、膻 脱整復、怒責抑制において運動失調か認められない、作用持続時間が著しく長い、䖝度の 镇静が認められる、等の特徵があり、無痛覚領域がやや狭い、作用発現時間がやや逑いと いう点は術式で考虑することにより十分カパーすることが可能であった。 
12. 癲疬様発作を主徵とする黒毛和種子牛の一症例 西宮 弘* 菅野 労 斉藤一秋 小松 茂 高橋勝晤 （* 秋田県農共連中央部家畜診療所）
14. 新生子牛に見られた精巣の奇形腫について 栄 利文* 横山哲郎 浜名英政 佐藤義男 角田元成 村上弘正 （）福島県農共連浜家畜診）

類箱は原因が不明で、㮸に病理解剖上の確定的な变化を発見しえない

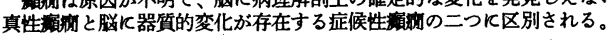

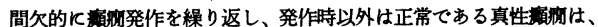
牛では極めてまれであると考えられている。

今度演者らは、生後九日目より耀留様発作を主政とする黒毛和種牛の 一症例K遭遇し、発症から警死、病理解剖に供するまで約四ヶ月間、臨 床獣医学的観察とともに媨波湘定わよび病理学的検索を実施したととろ、 興味ある所見が得られたのでその概要を報告する。

$1:$ 臨床所見

症例は平成 2 年 4 月 28 日生まれの黒毛和種子牛で、生時体重は 32

k gであった。

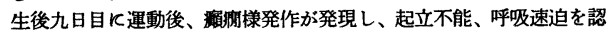
めた。

発作は一日 $2 \sim 3$ 回反復し、発作時間は $10 \sim 30$ 分持続、また発作 の前後に $5 \sim 6$ 時間は沈椎、横卧を認め、発作時には間代性氫学、起立 不能、瞳孔散大、眼球振盪、泡沫性流诞を認めた。

$2:$ 血液検查所見

特に、著変は認められなかった。

$3:$ 脳波所見

覚醒時に棘波が散見され、をた音刺激を加えるととにより一致したV 字波形を呈した。

呼吸促進剤の賦活により座杽や瞬目発作が発現した。癩㾈発作中の脳 波も記録できた。

4 : 病理学的所見

肉眼的には、大脳及び小脳には出血や壊死病巣が認められず、小脳は やや形成不全を呈していた。

組織学的には、大脳皮質に散発的に神経細胞の虚血性不全壊死を認め た。

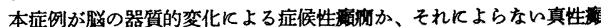
躱であるかは確定できなかった。

\section{3. 黒毛和種の悪性血管周皮腫の一症例}

\section{鷹觜 博* 村松栄一 上田潤司 小川徹三 \\ （* 岩手県紫波地方農共組家畜診）}

1.はしいる

今回病理学的検索の結果、牛の悪性血管周皮腫と診断された症例に

遭遇したので、その臨床所見と病理所見について活うこくする。

2 . 症例

紫波町て飼育されている黒毛和種、繁殖用堆 9 才の牛て、整告は 1

0 日前より前胸部の腫大を認め初診時食思不振、T $38.8 \mathrm{C}$ 、体表

被毛粗、光沢弾力を欠き、可視粘膜充血、第一胃運動減以外、循環器、

呼吸器等、聴診上異常を認めず、直腸唡査でリンパ節腫大等認めず。

右側前胸部小児頭大に腫大し表面柔らかく内部硬固感を示し、穿針の

結果血液流出の状態を示すので血腫を疑い消炎棛を処置し様子を見る。 血液唡査の結果、血球数、へモグラム、蛋白等は異常を示さなかった が、GOT、C F K の上昇と、L D H 活性檤の上昇及びアイソザイム バターンの2 と 30 上昇を認め、又B L Vゲル沈反応は（一）で有っ たのて悪性腫瘍を疑う。超音波断層像では内部沉巨大な腫瘤の存在が うかがわれた、その後腫脹の增大、削瘦著明の為廃用とする。

3. 病理所見

剖娭の結果右側浅胸筋及び深胸筋に $40 \times 30 \times 25 \mathrm{~cm} 、 15.5$ $k g の$ 腫瘍塊を認め浅頚及ざ肺、䀒、胸壁等に転移栄を認める。組織標

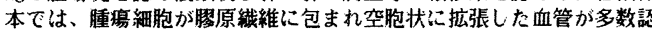

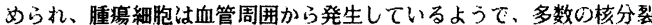
像を示し悪性度が高い事を示している。剖検により胸前部に於计る悪 性肉腫及び転移、組織学的沉覀性血管周皮腫と認め引れた。

4. 考察

本症例は、病理組織学的に悪性血管周皮腫と診断されたものて、牛 ては非常に希な例と考えられる。よって生前に於什万確定診断は困蜼 であったが、嗅床的に胸前の血腫に類似しながらも中心部に硬固物を 触知し、かつL D H の著增と、アイソザイムの 2 と 3 のバターンの増 加、並びにB L V (-) の結果により、牛白血病以外の腫瘍性疾患と 診断されたもので、今後の臨床診断の参考になるものと思われる。

15. 周産期乳牛とその産子の血液並びに乳汁中 $\boldsymbol{a}$-トコ フェロールの推移

熊田昇二* 金子幸江 本間鴙太 （* 日本全薬工業(侏)中央研）

1.はじめに

ビタミンEはセレンと共に生体の血中及び絴胞内での抗酸化作用に関与し、特に 㩆近好中球の殺菌能や抗体産生能との保かりが注目されている。そこで今回飼料变

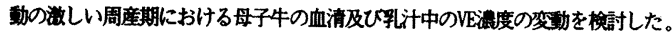

2. 材料及ひ方法

平成元年秋から平成2年春にか外て分媔した買北の一農場で ン種乳牛とその産子9組を用いた。分晩子定前28日目から分晩まで1周每に、分婏 後はその痤子と共に分婏当日を0日として1、3、5及ひ7日目に、その後は49日目ま で1周每に探取した血清及び全乳を供武した。 $\alpha$-トコフェロール(以下VE)の定量 はHPLC法を用いた。なお、子牛は生後7日目までは母乳を、それ以降乾草とスター ターを粭与し、合乳または代用乳(䉼8 $\mathrm{Kg} /$ 日)は は 1 ケ目まて粭与した。

3. 成 橉

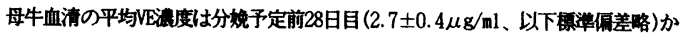
ら分婏時にか壮て減少し $(1.6 \mu \mathrm{g} / \mathrm{ml}) 、 そ の$ 後满增して 49 日目に最大值 $(4.9 \mu \mathrm{g} / \mathrm{ml})$ を示した。子牛血清の平均VE湌度は生後0日目の最小值 $(0.2 \mu \mathrm{g} / \mathrm{ml})$ 加急速に增加 して5日目に最大值 $(1.6 \mu \mathrm{g} / \mathrm{ml})$ を示し、その後、21日目まではそれより若干低い值

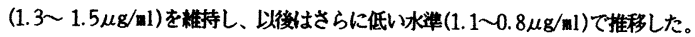

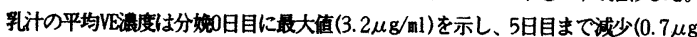

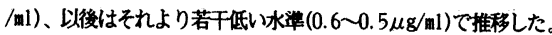

4. 考 察

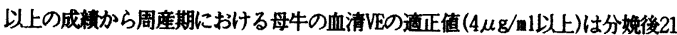

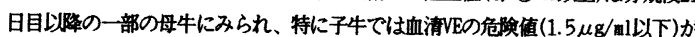

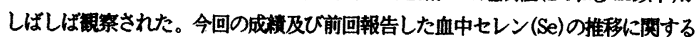

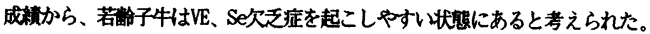


講演要旨一東 北

\section{6. 採卵後の処置が発情回帰および採卵間隔短縮に及ぼ す影響}

\section{菅野美樹夫* 高野 徹 佐藤尚史 佐藤照夫}

\section{（＊福島県畜産試験場）}

1. はじめに

牛の受精畉移植技術は凍結技術の確立により普及段陼に入ってきた。普 及にあたってはまず供卵牛の良質受精莭を多数得ることが必須条件である。 良質の受精卵を多数、安定して得るための要因として性腺刺澈ホルモンの 種類、投与量、間隔、時期、反復投与等が上げられる。演者らは第 5 回東 日本家畜受精卵移植技術研究会大会においてF S HとHMGを比較してH M G 投与で正常卵率が高まることを報告した。今回は採卵間隔短縮を目的 に浐瞅後の姏置の違いから检討したので報告する。

に财料および方法

供試牛は福島県畜産試験場繋養黒毛和種で、すでに 1 ～5回の採卵を行 っている20頭を用いた。スタンデング発情後 9〜1 1 日より豚下垂体 由来の性腺刺澈ホルモン F S H - R (L H含有量 $0.8 \%$ :アントリン) を総量 $24 \mathrm{AU} 、 3$ 日間漸减投与し、過剩排卯誘起を行った。発情誘起は 木ルモン投与 3 日目にP G F $2 \alpha$ (プロナルゴンFーアップジョン) を朝 ホルモン投与 时にPGF を0日として7および 8 日目に緋外科的にバルーンカテーテルを用いて回 収を行った。採卵後の処置として武験A区は、ヨード剂 (イソジン) 50 c c の子宮内注入のみ、試験 B区は $2 \alpha$ を $25 \mathrm{~m}$ g筋肉内投与した。A，B区共に、次過剩排卯処理までに 2 回以上の定期発情を確認した。試験C区はB区同様の採卵後処理を行い、 発情回㷌後ただちに過剩排卯処理を行った。 3. 成 綪

A区では採卵後の発情回帰は平均 24 日であった。これに対してB，C 区では平均 8 日であり、最も早いものは 6 日であった。A区の 1 頭当りの

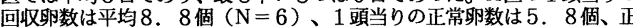
常卵率 $66 \%$ であった。B区では回収卵数が平均 9.5 個 $(\mathrm{N}=11)$ 、 正常卵数が平均 6.0個、正常卵率63\%で、处理後の採卵では回收卵数 が平均 90 個、正常卵数が平均 599 個、正常卵率 $67 \%$ であった。

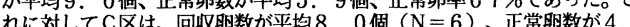
8 個、正常莭率 $60 \%$ で、处理後の採卵では回収畉数は平均 6.2 個、正 8個、正常卵率 $60 \%$ で、处理後の採卵では回収卵数は平均 6.2 個、正

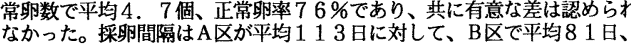
C区で平均 30 日であった。

以上の結果、上記の方法により採卵間隔の短縮は可能であると思われた。

\section{7. 自然発情期における授精後の 1 卵採取を指標とした} 供胚牛選定の実用性

千葉健市* 高橋達典 （）岩手県遠野家畜保健衛生所）

1. はじめに

牛の肧移植技術の実用化対策として、農家が飼養している敏殖牛を供胚牛と する「農家採卵」が行われている。しかし、過剩非卵処置によって正常肧が回 収されないことや空胎期間が延長することがある。これらを改善するために、 自然発情期における授精後に 1 卵採取を行い、その採取成績を指標とした供肧 牛選定法について検討した。

2. 材料と方法

供肧牛は、管内の農家に飼餋されている黒毛和種19頭、ホルスタイン種 4 頭 を用いた。分婏後初回ないし 2 回目の発情期に人工授精を行い、授精後6-8 日 に肧を回収した。過剩排卯処置汸発情後9-13日よりFSH 堿量 (28-36mg)-PGF $2 \alpha$ 法で行い、授精後 7 日に非手術的に肧を回収した。また、発情期加ら 1 卵採取 を行うまでに、血中の絵コレステロール值が黒毛和種では $90 \mathrm{mg} / \mathrm{d} 1$ 、ホルス夕 イン種では $120 \mathrm{mg} / \mathrm{d} 1$ 以上であることを確認した。

3. 成 績

(1) 1 卵採取で正常胚が回取されたのは、黑毛和種 9 頭、ホルスタイン種 4 頭で、いずれも過剩排卵処置によって正常胚が回収された。その平均正常肧数、 正常肧率は、黒毛和種で10.4個、68\% 、ホルスタイン種で14.0個、95\%であっ た。1 卵採取で正常胚が回収されなかった黒毛和種10頭のうち過剩排卵処置に よって正常肧が回収されたのは 5 頭で、その平均正常肧数、正常肧率は、1.6 個、25\% であった。(2) 正常胚のうち優秀胚の割合は、1 卵採取で正常肧を回 収された黒毛和種で71\% 、ホルスタイン種で82\% と高い值であった。(3) 肧回 収後受胎するまでの日数は、1 卵採取で正常还が回収された黒毛和種で34日と 正常胚が回収されなった牛の63日により有意に短かった。(4) 1 卵採取によっ て技術者に対する技術指導、農家への技術実証展示の回数が增した。

\section{4. 考 察}

自然発情期における授精後の 1 卵採取で正常胚が回収された牛では、その後 の過剩排卵処置によって正常胚が確実に回収され、肧回収後の受胎率も良いと 考えられた。また、1卵採取は、技術者や農家への技術指導の場としても有効 であった。
18. 一養豚場に発生した哺乳子豚のゲタウイルス感染症 について

\section{本間純一朗* 清野昌夫 伴 顕 矢口直安 \\ （* 山形県農共連最上家畜診療所）}

1 はじめに

ゲタウイルス ( G V) はトガウイルス科アルファウイルス属に属するウ

イルスである。子䀠のGV感染症例は我国において1985年10月神奈川での

発生が報告されて以来、埼玉、鹿晶島で報告があるのみである

今回、哺乳子豚が神経症状を呈し死しする症例に遭遇し病性鑑定を実施

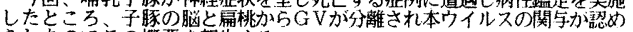

られたのでその概要を報告する。

.材料および方法

材料は10月8 日から12日にかけて登症した4㩆と死亡豚2 䫓、神経症状

を示さなかった同腹豚 4 頭の10頭を病性籃定材料とした。

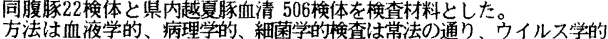
検查でウイル血液学的、病理学的、細菌学的検查は常法の通ク、ウイルス学的 検查でウイルス分離にCP K細胞を使用し分離ウイルスについてGV免疫 血清試験を実施した。

. 成 績

(1) 豚=1レラ、日本脳炎、オーエスキ一病、䀠パルボウイルス感染症及

び細菌性疾病は否定された。 られた。

(3) ウイルス学的娭査で唡查した 3 頍すへての䏚と扁桃からウイルスが 分離され分離ウイルスはガチョウ血球を凝集し、GV免疫血清で中和され、

電子離微鏡学的に観察したところGVと同定された。

子登のGV 感染症例は、これまで東北での発生報告はなくこれが初めて の発生である。

今回神経症状を呈して急死した 2 週令の子豚について種々娭榃の結果、

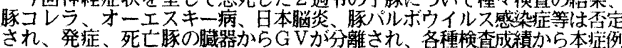
は、GVの感染により蚛度のウイルス血症を起こし急性経過をとつたもの と示㖫された。

これまでの報告例は発症日令が 1 週間以内と若く病理的に変化がかか たのに対し、本症例は15〜18日令で発症し、脑有膜下の出血と非化澧性脑

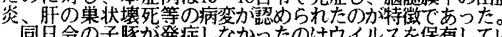

闰日令の子豚が発症しなからたのはウイイルをを保有している䀠が少なく 感染考受けなかったか、䀠での G V 血症のレベルと持続時閌十分でなか力 ももと考えられた。

この時期の子姐の発症はGV感染拄を強く疑い早期に適切な検査を実施 㻅断す心きと考えられた。

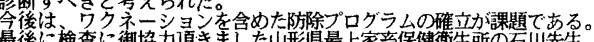

最後に梌查に衔協力頂きました山形県最上家音保健衙生所の石川先生。

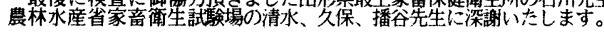

19. 免疫不全状態が疑われた BVD-MD ウイルス感染子 牛の一症例

伊藤 敦* 渡部正樹 山田稲生
高橋勝一
（* 宮城県仙台家畜保健衛生所）

1. はじめに

BVD-MDイルス感染症は多彩な病態を示すか、、特に持続感染と粘膜病との関 連については免疫学的な問題む含め注目されている。今回、粘膜病と㟝断され た子牛にいくつかの免疫不全状態を示唆する所見を認めたので報告する。

2. 材料および方法

供試材料は、鑑定殺した 6力月齢の黒毛和種で、細菌、ウイルス、組織、血 液生化学の各種検查を実施しするとともに、大脳の切片について抗BVD-ND鬼血 清を用いた醉素抗体法も実施した。

3. 成 績

5力月齢より水様性の下莉や発熱を示し抗生阂等による治療を継続していた が、症状が改善されないため鑑定殺した。本例は双子で他の1頭も約 1 力前 に同様の症状を呈し死亡していた。剖検所見としては、内股部や芫根部、外陰 部周册の脱毛之全身皮覻における黄蝎色浸出物の付着、舅鏡や踣冠部、舌、第 三・四胃粘膜における清幏、小腸および大晹粘膜の充血とび爛、体表および脂 間膜リンパ節の軽度腫大、胸垂部や大腿骨周囲における膠様浸潤などが認めら れた。組織検查では、皮層、舅鏡、舌、食道、第三・四胃などの潰湢部におけ る化膿性細胞の重度の浸潤、小腸や大腸粘膜における陰裔の㹡張、全身のリン ハ節におけるリンパろ胞の形成不全、中小動脈壁の硝子様変性、軽度の力夕ル 性肺炎、畈紐胞の空胞变性や巣状壊死、大脳における軽度のグリア細胞の集簇 などが認められた。主要藏器からは有意な紐菌は分離されなかった。BVD-MDの 中和抗体価は陰性であったが、脾、腎、心、肺、小腸、血液からCPE(†)のBVDMDウイルスが分離され、抗BVD-ND鬼血清を用いた酵素抗体法では大脑神経細胞 の細胞暂に陽牲抗原を認めた。血液生化学検筸では、,-Globulinの著明な低下 $(0.63 \mathrm{~g} / \mathrm{d} 1)$ や白血球数、血清総蛋白、Retinol、T-Cholesterolの減少とCK、 GOT、GPT、シアル酸の増加を認めた。

4. 考 察

;-Globulinの著明な低下や全身りン八節におけるろ胞の形成不全などから免 疫機能の低下が示唆され、BVD-MDウイルスの感染との関連性が推察された。ま た、酵素抗体法よりBVD-MDウイスの標的細胞として神経細胞が注目された。 
20. 12 年間におけるウシ白血病ウイルス非污染牧場の 確立

吉川博康* 吉川 卉 小川弘之 小山田敏文 佐々木卓士 椿 志郎 (* 北里大学獣医畜産学部)

ウシ白血病の中の成牛型はウシ白血病ウイルス（B L V ）の感染に基づく 伝染性疾患である。しかもその発生は慢性的経過をとり、臨床的に発賞した 封点では予後の見込みは望めないのか現状である。加えてBLVのゲノムは 標的紻胞であるリンノ球に組み込まれている。従って一旦BLVに感染した 牛体は終牛ウイルスを保持しており、B LV 感染保有㝛主として感染源とな つている。BLV感染牛のすべてが発癌に進展しないか、不顕性のまま経過 するのて、発病の有無に拘らずBLV感染牛は最も重要な本病の感染源とな っている。従って本病の予防に関しては現状下では、B L V 感染牛を摘発し 淂離・淘汰することが求められる。それには寒天ゲル内沈降反応 (AGID) を 用いた診断が最も実用的であり、我か国では声川ら(1981)、大島ら(1988)、 (藤ら(1990)によ一て既にその可能性か証明されている。

本報告は清浄化牧埸を 12 年間に亘り、その維持に成功するとともに、AGID 法による B L V 感染牛の陽離ないし淘汰は確実に本病の䂆防を成し得ること 在㹬明したものである。

非污染牧場は先に報告した北里大学附属八雲実験牧場である（1981年 Jpn. J. Vet. Sci. ) 。B L V 感染診断液 (北里抗原) を用いた抗体調植は 1977年9月から1991年5月までの14年間に25回、延べ6712頭について行った。 北米抗原によるAGID法で B L V 感染の有無を検相し、陽性牛は速やかに十和 由闲の大学牧場に移動した。

その結果， 1 回月 (1977年9月) 陽性率 : $3.52 \% 、 2$ 回月 (1978年5月)

$: 2.12 \% ， 3$ 回目 (同年11月) : $11.39 \%(22 / 193$ 頭)、4回目（1979年5 月）: $5.61 \% 、 5$ 回目（同年 8 月）: 3.39\%および 6 回目（同年11月）から 前頭力陰吽に転じた。その後、1980年から1991年の12年間に毎年 2 回、AGID 法を実施したが、いずれの年においても陽性牛は指摘されなかった。

\section{1985 年の自然感染牛におけるアカバネウイルス中 和抗体価の推移}

斎藤久孝* 吉田欣哉 大池裕治 吉川恵郷

（* 岩手県盛岡家畜保健衛生所）

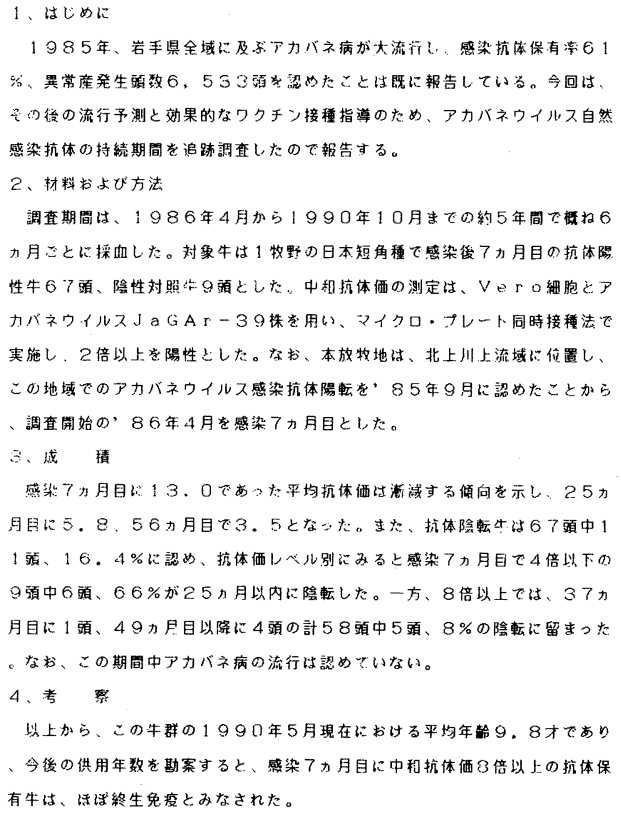

22. 日本短角種肥育牛にみられたビタミン $\mathrm{A}$ 欠乏症 内藤善久* 大泉俊昭 佐藤れえ子 村上大蔵

（* 岩手大学農学部）

1.はじめに：最近, 肥育牛の多頍䝭育化にともない, 飼料の効率化や脂肪 の黄色化を除くため, 飼料中のビタミンA量を少なくする風潮にあり，その結 果, ピタミンA欠乏症の発生は増加する傾向にある. 今回は日本短角㮔肥育牛 に見られたビタミンA欠乏症について報告する。

2. 症例： 本発症農家は, 日本短角種肉用牛の肥育仕上期のもの 7 ○頍を預

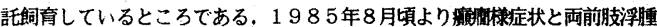
を呈するものが散発し，と畜模查時に全身筋肉の水腫性変化力淜膫となり， 10 月までに 11 頭が全廃棄されたため, 同様の経過をたどると推察された 1 例を本学家畜病院に搬入させ，その原因究明を依頼された。

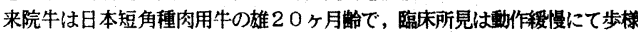
蹌踉，両前肢は腫張し開脚努势をとる。胸前を中心に浮㣫力゙見られ，両眼球は 軽度突出し，瞳孔反射は鈍い，血液検查所見で，軽度の貨血を認めた以外に は著変を惩めなかった，以上の主として，臨床症状からビタミンA欠乏症疑 われた.よって，同居牛の娭査のため，対照を設けて臨床所見と血中ビタミン A浱度の測定などを行なった。牛群は, A群が本発症農家のもので軽度の発症 がみられた日本短角種肉用牛 (雄) の約 20 ケ月数のもの 9 頭, B群は明膫な 臨床症状は見られなかったか飼美形態力類似し䀦料成分が渃干異なる同種のも の5頭，およびC群は全く飼養形態及び飼料成分の異なるホルスタイン種乳用

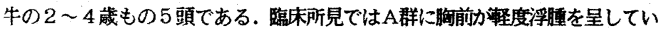
るもの8頭，前肢の軽度腫張するものが5頭見られた．B群で胸前にわずか な浮腫を示すもの 4 頭か涀られたか，C群には臨床症状に異常を呈するものは

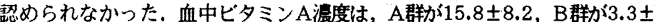

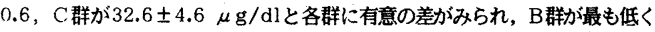
A群では個体間の差が著しかった， A，B群の白血球数はC群に比較して有意 に增加し, 黄㾝指数は有意に低下した。

3. 考察： $\mathrm{A} お よ ひ ゙ B$ 群はいずれも明らかなビタミンA欠乏症を呈してい

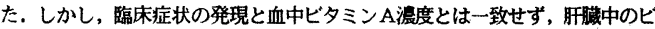
タミンA量あるいは血中レチノール結合たんぱく搌度などか蝪床発現に深く関 与している可能性が示唆された。

23. 山羊の実験的尿毒症に関する研究 : 尿管絞扼後の酸 ・塩基平衡と第四胃ならびに腸管の運動と電解質の関 連性について

$$
\begin{aligned}
& \text { 小笠原俊実* 滝沢直樹 服部慶嗣 } \\
& \text { 河原 智 } \\
& \text { (* 北里大学獣医畜産学部) }
\end{aligned}
$$

\section{1.はじめに}

反知獣の尿毒症における酸・塩基平衡障害について報告者により区区である。 一方、電解質の変化としては多くの報告は低Cl血症を呈するとしている。演者 らは山羊の尿道結紮により、実験的に尿毒症を発症させた場合、低Cl性代稚性 アルカローシスを呈したことを既に東北家畜臨床研究会報に発表 (1986) した。 今回、尿路の閉塞部位を変えた場合の酸・塭基障害の出現の有無、血清電解質 と第四胃汁電解質の変化の観察と尿毒症時における低Cl血症の原因の一端を解 明するため、以下の実験を行った。

2. 材料および方法

6 頭の成山羊の両側尿管を人為的に絞扼し、尿毒症を発症させ、酸・塩基平 衡と電解質、第四胃汁のpHと電解質の動態を山劷死亡するまで観察し、あわ せて血清Cl濃度と第四胃汁Cl濃度の相関性についても㭘討を加えた。また、X 線透視により第一胃の運動を観察するとともに、第四胃内に硫酸バリウムを投 与し、第四胃と腸管の運動を経時的に観察した。

3. 成 績

動脈血pH、 $\mathrm{PCO}_{2} 、 \mathrm{HCO}_{3}$-およびBase Excessは実験経過中に正常値範囲内を推 移し、P02は低下傾向を示した。第四胃汁pHは著明に低下した。血清Naは減少傾 向を示し、第四胃汁Naは増加傾向を示した。血清Kは著明に増加し、第四胃汁は 減少傾向を示した。血清Clは著明に隇少したが、第四胃汁Clは著明に増加した。 血清Cl濃度と第四胃汁Cl濃度との間には負の相関（r=-0.715）がみられた。 $\left(\mathrm{Na}^{+}+\mathrm{K}^{+}\right)-\left(\mathrm{Cl}^{-}+\mathrm{HCO}_{3}^{-}\right)$の式で求めたAnion Gapは著明に増加した。 第一胃運動は徐々に滅少し、未期には停止した。また、第四胃と腸管運動も渐 次弱くなり、6頭中 4 頭で第四胃の運動が停止し、拡張した。 4. 考 察

以上の成績から、腎後性の尿書症でも閉塞する部位によって、酸・塩基平衡 障害に差異がみられることか明かとなった。また、尿毒症時にみられる低Cl血 症は、第四胃で胃液が分泌されるが、第四胃と腸管運動の抑制により、第四罢 内にClの賍留か起こり、腸からClか吸収されないことも一因と考えられた。 
24. 細胞質内にグリコーゲンを認めた牛の造血器系腫瘍 佐々木英知* 斉藤 益 阿部知行 斎藤俊逸

（）青森県青森家畜保健衛生所）

\footnotetext{
症例は、日本短角種、1 0 紫 3 か月部の㖪で、牧野に おいて、腹部脚满と胸垂の下垂が見られ、歩行困鹳に陥 り、と畜埸への铪送作業中に整死したものである。外景 からは腹用膨渵、全身性の浮腫、口㓐及ひ腈からの出 血が認められた。全身の脂肪沈着は良好て、、皮下倳及び 筋間は水腫が著しく、体表リンバ節も水腫性に睲大して

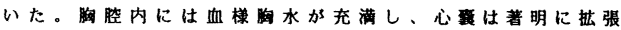
していた。心腈ては外膜全体に淡黄白色の脂肪様物か䋈 状に高度付着し、全体の大きさは人頭大より大きかった。

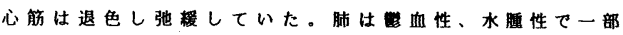
の実質に黄色巣が散見された。腹腔内では麦桿色の腹水 增量、高度脂肪沈着及ひ獎膜間水腫が㝬められた。大睤 周囲の脂肪租樴は硬度を增し、一部に脂肪壤死が認めら

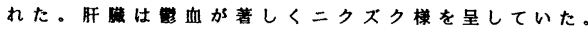

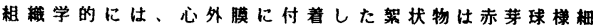
胞の著しい增殖からなり、耕胞質はPAS 究色でしばし ば陽性に染まり、電影により、その陽性物質はクリコー ダンであることが確瑕された。
}

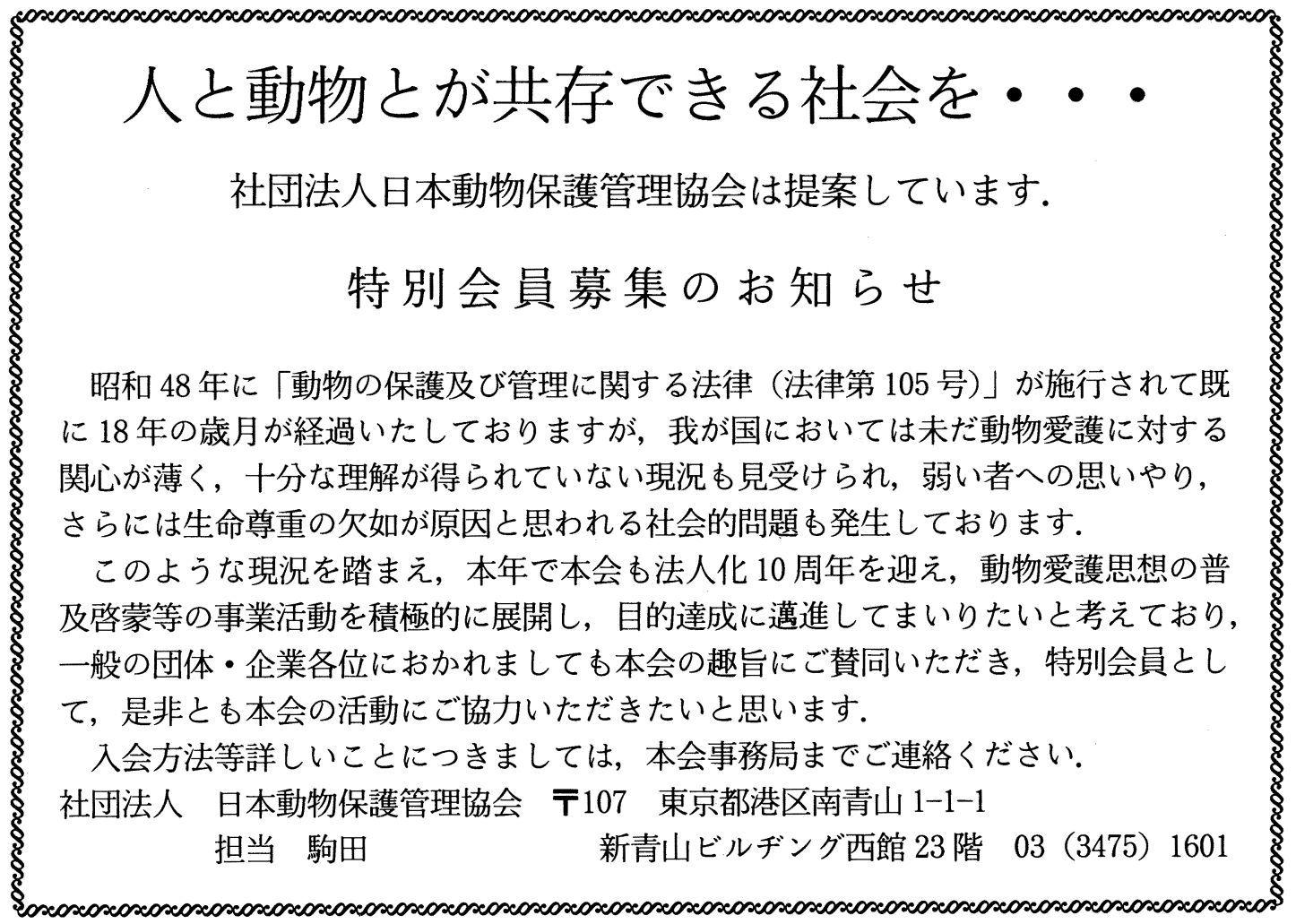

